\title{
Chillida y la mística alemana
}

\section{Chillida and the German mystic}

\author{
Arno GIMBER \\ Universidad Complutense de Madrid \\ agimber@filol.ucm.es
}

\section{Resumen}

En tres pasos paradójicos se aborda la importancia del ideario de la mística alemana, en especial de la obra de Meister Eckhart, para Eduardo Chillida: la representación de lo no-representable, el vacío lleno de luz y la música en el silencio son elementos que impregnan la creación artística del gran escultor español. Están claramente relacionados con la mística alemana.

Palabras clave: Mística alemana, Meister Eckhart, paradojas místicas, Chillida

\begin{abstract}
Three paradoxical steps deal with the importance of the ideas of German mysticism, especially the work of Meister Eckhart, to Eduardo Chillida: the representation of non-representable, the vacuum filled with light and the music in silence are elements that pervade the artistic creation of the great Spanish sculptor. They are clearly related to German mysticism.
\end{abstract}

Key words: German mystic, Meister Eckhart, mystic paradoxes, Chillida 
Desde el espacio / con su hermano el tiempo / bajo la gravedad insistente / con una luz para ver como no veo. / Entre el ya no y el todavía no / fui colocado. / El asombro ante lo que desconozco fue mi maestro. / Escuchando su inmensidad. / He tratado de mirar, no sé si he visto.

Eduardo Chillida

\section{Inicio: El asombro del místico o la adoración callada}

Las líneas arriba citadas nos sitúan en el mundo místico de Chillida, y las conexiones con el tema de la mística alemana quedan evidenciadas. Quizá falte en este poema una alusión a la música, que se considera igualmente importante en el ideario místico de Chillida, pero sea como fuere, el objetivo último de esta contribución no es de demostrar en qué autores o textos se basaba el artista cuando creaba determinadas obras (además sería imposible y una tarea sin sentido alguno) sino más bien aclarar en qué medida la mística alemana (o incluso más allá de una categorización nacional desde el neoplatonismo de Plotino y sobre todo de Pseudo Dionisio-Areopagita) facilita un mayor acercamiento a la compleja obra de Eduardo Chillida.

De antemano hay que decir que la relación entre Chillida y la mística alemana es más bien difusa. Cuando en las entrevistas se le preguntaba al artista cómo había llegado a ella, solía contestar que a través de San Agustín y a través de la música. Y solía nombrar a tres místicos alemanes: a Meister Eckhart (hacia 1260-1328), a Jakob Böhme (1575-1624) y a Suso (1295-1366), también conocido como Heinrich Seuse, alumno del primero. En una conversación de 1996 con Sanjuana Martínez, Chillida amplió esta nómina de nombres: "Sanjuana Martínez - ¿La mística ha influido en su obra? Eduardo Chillida ¡Jope!, de manera fundamental. En París empiezo a interesarme por los autores alemanes: Goethe, que tiene un libro interesantísimo sobre la teoría de los colores, Eckhart, Suso, Hölderlin, Novalis, los conocí bastante tarde." La lectura de estos autores se produjo, pues, en francés (o en castellano ya que las traducciones por lo menos de algunas obras de Meister Eckhart eran ya conoci-

\footnotetext{
${ }^{1}$ Entrevista citada en la página web de la Asociación de amigos del arte y la cultura de Valladolid: http://www.ddooss.org/articulos/entrevistas/eduardo_chillida.htm (última consulta 8 de marzo 2013).
} 
das a mediados del siglo XX). Meister Eckhart y Suso sí, pero Goethe, Hölderlin y Novalis, en el sentido estricto de las clasificaciones filosóficas y estéticas, no son autores místicos. Sin embargo, no se puede negar la existencia de pensamientos místicos en ellos e incluso Johann Sebastian Bach, a quien Chillida no incluye en esta relación, bien merecería formar parte del grupo.

La palabra mística (y esta aclaración importa) significa entre otras cosas "culto secreto" o "sabiduría secreta", es decir un conocimiento más allá de lo establecido. También existe un significado de la mística derivado del griego "myô" como "encerrarse", "cerrar los ojos y la boca" no por decepción sino por motivos de asombro y como expresión de una comunicación suprema. En el estado místico el hombre se enfrenta a secretos que le fascinan pero que no puede y sobre todo ni siquiera desea explicar y ante los que solo queda la adoración callada y el asombro. Pseudo Dionysius-Areopagita, el místico que con Plotino más ha influenciado en los místicos alemanes de la Edad Media, abre, en este sentido, el camino hacia una teología mística. Para él, la mística es un fenómeno religioso en el cual se produce en una intuición inmediata la vivencia de Dios. A diferencia de Tomás de Aquino, que define la mística como cognitio Dei experimentalis, como una experiencia fundamental de un contacto directo con Dios o más bien, ya que aquí no vamos a seguir un discurso teológico, con la realidad metafísica primaria, Pseudo Dionysius-Areopagita aporta una variante a esta observación e insiste en que el acto de la unio mystika no puede ser descrito con una terminología terrestre por lo que se habla en estos contextos a menudo del silentium mystikum o de una teología negativa. $\mathrm{He}$ aquí ya el carácter de paradoja de la experiencia mística, y con ello de alguna forma ya estamos entrando en la problemática que va a ser abordada en el primer punto de este artículo.

Pero antes y en relación con Chillida hay que mencionar aún a Ludwig Wittgenstein. Quiero referirme a una de sus frases más conocidas del Tractatus Logico-Philosophicus y que dice que "das Gefühl der Welt als begrenztes Ganzes ist das mystische" ("sentir el mundo como un todo limitado es lo místico" $)^{2}$, lo que en la línea arriba dibujada nos lleva a los límites de la existencia de lo efable o expresable. Lo que importa a mi parecer es que la palabra es limitada, y el sentido y valor del mundo deben encontrarse fuera de sus límites. Según esta frase 6.45 al sentimiento místico corresponde la contemplación del mundo bajo la perspectiva de lo eterno y el Tractatus clasifica esta actitud mística como algo que no se puede pronunciar o decir y que exclusivamente se

\footnotetext{
${ }^{2}$ Wittgenstein, L., Tractatus Logico-Philosophicus, Frankfurt/Main, Suhrkamp, 1998, 6.45(tr. nuestra).
} 
demuestra: "es gibt allerdings Unaussprechliches. Dies zeigt sich [...]" (hay ciertamente lo inexpresable. Se muestra). ${ }^{3}$ He aquí la oportunidad del artista. La diferenciación entre expresar con palabras, decir y mostrar (sagen und zeigen) juega un papel central en el discurso lógico-filosófico de Wittgenstein, y en ello reside, según Bertrand Russell, el problema principal de la filosofía. Lo místico es entonces lo que se muestra (anzeigen) como lo inefable (das Unaussprechliche) en los límites de la percepción (Wahrnehmung) del mundo como entidad limitada, "in der Welt als begrenztem Ganzen".

He aquí el marco en el que me voy a mover ahora entrando directamente en la obra de Chillida. La trataré desde los tres puntos ya aludidos: la paradoja mística, la luz y la música.

\section{"Waz klârheit an götlîcher natûre sî, daz ist unsprechelich" o la paradoja mística}

Meister Eckhart no fue el único en su tiempo que llegó a formular una paradoja mística que consiste en lo siguiente: un Dios que supera nuestra capacidad conceptual (Begriffsvermögen) no puede ser comprendido a través de nombres y atributos afirmativos tal y como los expresamos en una lengua. Este intento de comprender a Dios tiene que fracasar ya que todo lenguaje humano es finito. Dios es y no es, es lo contrario, es todo. Ya Pseudo Dionysius-Areopagita en el siglo sexto intenta acercarse a Él a través de la negación de sus características, es decir combinando palabras con su contrario. Aunque así tampoco se alcanza asir el significado, permite acercarse a él. La paradoja es entonces una operación digamos dialéctica en la que una tesis y su antítesis se excluyen entre sí para que la síntesis de esta operación no se pueda expresar, pero sea deducible mentalmente. Por un lado esta operación se refiere a los contenidos de las cualidades negadas, por otro los trasciende. En Meister Eckhart encontramos por ejemplo la formulación "Der aber bi nihte von gote redet, der redet eigentliche von im", es decir por un lado Dios no es comprehensible (y por lo tanto no se le puede describir con palabras), por otro cada uno se debe acercar a él, a lo inconcebible que es, con las posibilidades lingüísticas limitadas. Ocurre algo parecido con las obras de arte de Chillida: conceptualmente es difícil de entender su síntesis, y la paradoja funciona como un mostar dialéctico de la trascendencia.

\footnotetext{
${ }^{3}$ Ibidem, 6.522 (tr. nuestra).

${ }^{4}$ Meister Eckhart, «Predigt 71» en Meister Eckhart, Werke II, Frankfurt/Main, Deutscher Klassiker Verlag, 1993, p. 72, líneas 18-19.
} 
Por ejemplo en Yunque de los sueños (hierro y madera, 1962) transparenta la oposición de contrarios, cuya energía mueve -en opinión de Jacques Dupin ${ }^{5}$ - la obra.

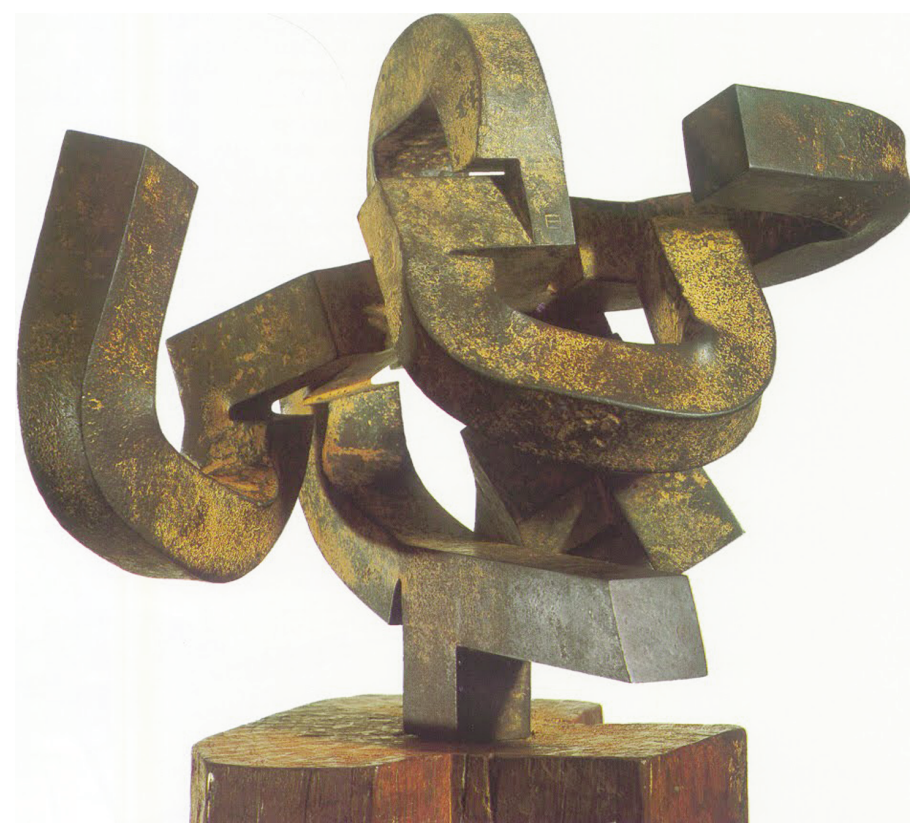

Los brazos sólo estarían separados por un "vacío intersticial", ese lugar (equivalente a la nada de Meister Eckhart) en el que -para Ángel Valente- la mística sitúa a Dios. En esa idea también insiste Octavio Paz cuando dice de Chillida que "sus esculturas son la estancia del espacio y están habitadas por un ser plural y único.” Chillida mismo lo llamará "espacio interior", pero también lo podríamos denominar vacuidad, espíritu, logos o Dios. Tiene todos los nombres y ninguno y nos acercamos a él a través de oposiciones. Meister Eckhart inserta muchas en su obra, y para conseguirlas utiliza metáforas atrevidas o paradojas como "grundloser Grund", "fondo sin fondo", y "Ent-bildung" "des-representación". Esta última creación me parece crucial también para la comprensión de la obra de Chillida. Alrededor de ella y de otros conceptos como "Über-bildung" ("sobre-representación") o "Ein-erbildung" ("imaginación-representación"), Meister Eckhart formula una teoría de la imagen en relación con el desasimiento místico. Para Eckhart, la "Bildung" (dar

\footnotetext{
${ }^{5}$ Dupin, J., Chillida, terres et gravitations, Paris, Cahiers d'art contemporain, 1995.

${ }^{6} \mathrm{Paz}, \mathrm{O}$., «Chillida, entre el hierro y la luz» en la introducción al catálogo Eduardo Chillida, París, Maeght Éditeur, 1980.
} 
forma, formación y aquí representación o representabilidad) y la "Ent-bildung" (des-representabilidad) están estrechamente vinculadas, están en una relación dialéctica. Sólo el hombre que renuncia a la representación encuentra su propia naturaleza, y la experiencia de la profundidad del alma, del yo propio, en Eckhart es similar a la falta de imágenes, a lo irrepresentable por ejemplo en el budismo. Para él, encontrarse a sí mismo significa encontrar a Dios, significa el nacimiento de Dios en el alma humana. ${ }^{7}$ También Angelus Silesius utilizó el concepto de la "Ent-Bildung" en este sentido. Escribió: "Entbilde dich, mein Kind, so wirst du Gotte gleich und bist in stiller Ruh dir selbst ein Himmelreich". 8

Con esta experiencias de la unión mística entre Dios y hombre en lo infinito, en lo absoluto e innombrable más allá de espacio y tiempo, el artista moderno entra en regiones limítrofes: abandona la epopeya de la realidad en el retrato, en el paisaje y en la historia y se acerca a los contornos que demarca el silencio, a la últimas imágenes en el tránsito hacia la ausencia de imágenes, hacia un mundo de la experiencia inefable y pura.

Ampliando esta idea se puede decir que también la paradoja del arte abstracto (desde Malévitch al arte minimal) ha consistido en mostrar lo impensable ("das Undenkbare"), en hacer visible lo invisible ( $\alpha$ ó $\alpha \tau$ os, aóratos), representar lo irrepresentable ("Entbildung"); esto es, la trascendencia metafísica, morada de lo inefable que -de Plotino a Wittgenstein- se ha venido a designar como el territorio de lo indecible ("das Unsagbare"). La esencia ("das Wesen") de la imagen reposa en el fundamento de lo ausente, en lo que no tiene fundamento y que por lo tanto es abismo (“Abgrund”). Tanto la mística como el arte abstracto -en su recorrido común por la ontología de la imagenespeculan sobre ese desierto de lo inexpresable ("das Unaussprechliche"), que es el principio anterior al ser; espacio sin límite ("Unbegrenzheit"), abismo más allá de lo visible constituido de silencio y de reposo, en el que toda representación está de más. ${ }^{9}$

A partir de estas primeras reflexiones y su planteamiento en la filosofía medieval se encuentran teorías de lo inefable sobre todo en el romanticismo. Y entonces sí que podríamos mencionar a Novalis, del que conservamos un precioso fragmen-

\footnotetext{
${ }^{7}$ Véase al respecto Asmuth, Ch., Bilder über Bilder. Bilder ohne Bilder. Eine neue Theorie der Bildlichkeit, Darmstadt, Wissenschaftliche Buchgesellschaft, 2011, pp. 66-72.

${ }^{8}$ Silesius, A., Sämtliche poetische Werke in drei Bänden. Vol. 3, München, Hanser, 1952, p. 48: "deshazte de la cultura, niño mío, solo de esta forma te puedes igualar a Dios y ser así tu propio cielo en una silenciosa calma" (tr. nuestra).

${ }_{9}^{9}$ Tesis conocida y bien resumida en Carbó, A. G., «El arte abstracto y lo indecible: el fondo abisal de la obra de arte», Convivium, 2,11 (1998) pp. 128-151.
} 
to, conocido como Monolog, sobre la crisis del lenguaje avant la lettre, en el que apunta ya la negación de la función representativa del lenguaje. Friedrich Schlegel reflexiona sobre la incomprensibilidad ("Unverständlichkeit") y Friedrich Hölderlin se pregunta en uno de sus más conocidos poemas, Hymnische Entwürfe, por la región del no-saber y de la no-representación, en definitiva por la medida misteriosa de Dios: "Was ist Gott? unbekannt, dennoch / Voll Eigenschaften ist das Angesicht / Des Himmels von ihm. Die Blize [isic!] nemlich / Der Zorn sind eines Gottes. Jemehr ist eins / Unsichtbar, schiket es sich in Fremdes [...]"10. Todas estas cuestiones que ahora no podemos abordar, tienen una clara conexión con el pensamiento de los místicos alemanes y están relacionadas, aunque sea en una filiación confusa, con la creación de Chillida.

Antes de pasar al segundo punto me permito un inciso sobre procedimientos parecidos a los de Chillida en otros artistas ${ }^{11}$. Llama la atención que son sobre todo los asiáticos quienes coinciden con Chillida en asemejar su arte al ideario de la mística. La artista japonesa Rei Naito también trata de acercarse a Meister Eckhart con una sutileza ya no superable hasta tal punto que en sus exposiciones muchos visitantes ni siquiera se dan cuenta de sus obras y las destruyen sin querer. Una de ellas, por ejemplo, está hecha de un solo hilo de seda que cuelga del techo. $\mathrm{O}$ los puntos en unas vidrieras que se agrupan en una forma circular. Apenas son reconocibles incluso para los ojos que saben de su existencia.

Aparentemente los japoneses tienen menos dificultades para empatizar con el pensamiento de Meister Eckhart que los artistas del occidente cristiano. Ya Daisetz Suzuki, que popularizó la filosofía Zen en el siglo pasado en Occidente, dijo que las ideas de Eckhart podrían ser consideradas como consecuencia de la especulación budista. Por lo tanto no sorprende que los asiáticos y el pensamiento oriental sobre la mística dejen fuertes impresiones en el arte. Por ejemplo cuando en los dibujos sobre la pobreza y el rigor espiritual del gran calígrafo japonés de repente aparece la forma humana.

El videoartista Bill Viola, sin embargo, ha demostrado la transformación mística a través de la difuminación de la imagen humana sobre la inmovilizada superficie del agua de una piscina. John Cage se acerca a la regla de lo divino

\footnotetext{
${ }^{10}$ Hölderlin, F., Werke. Bd. 2,1, Stuttgart, Kohlhammer, p. 210: “¿Qué es Dios? desconocido, sin embargo / lleno de propiedades está el rostro / del cielo de él / Así los rayos / la ira son de un Dios / Tanto más invisible es una cosa ... cuando se destina a lo extraño [...]" (tr. nuestra). ${ }^{11}$ Las siguientes referencias son tomadas del catálogo Schierz, K.U. / Opitz, S. (dir.), Unaussprechlich Schön. Das mystische Paradoxon in der Kunst des 20. Jahrhunderts. Ineffable Beauty. Mystical Paradox in 20th Century Art. Ausstellung im Rahmen des kulturellen Schwerpunktes 2003 in Erfurt. 'Wege zu Meister Eckhart-Mystiker, Theologe, Europäer'. Kunsthalle Erfurt 4.5.-22.6.2003, Köln, Salon Verlag, 2003.
} 
en sus dibujos a través de lo aleatorio, Jawlensky o Marwan prefieren elegir la cara humana como entrada en el mundo trascendente. A Yves Klein le sirve el puro azul y Hiroshi Sugimoto opta para la mirada mística por la mirada fotográfica a la superficie del mar eterno y atemporal.

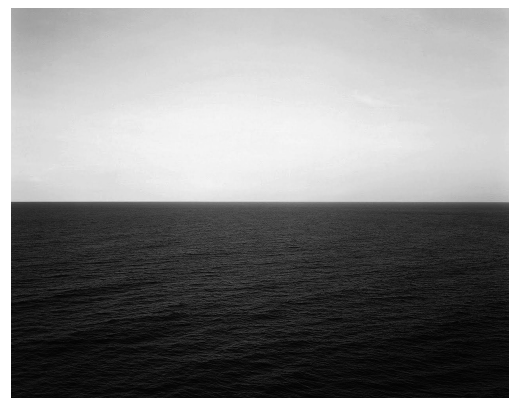

En todos estos ejemplos encontramos igualmente la paradoja ya que lo místico es, de hecho, lo irrepresentable y lo inefable. Tal vez precisamente por ello es tan estimulante el intento de comunicación que proponen. Y las posibilidades de hacerlo son múltiples. Eduardo Chillida interpreta, no hay que olvidarlo, en su proyecto subterráneo de Fuerteventura la imposibilidad de la representación de lo místico como un vacío lleno de luz.

\section{EI templo vacío o la luz}

La luz tiene un papel dominante en el pensamiento místico. Ya Pseudo Dionisio-Areopagita habla de Dios (conforme con lo que antes hemos llamado paradoja estética) como "luz de tiniebla" o "tiniebla luminosa", imagen ya presente en filósofos anteriores como Filón de Alejandría o Gregorio de Nisa, y retomada por San Juan de la Cruz como rostro divino que no se puede ceñir con la mirada pues es invisible a la visión humana. Dios es "aquel que está más allá de todo ser y de todo saber" y "la divina tiniebla" es "luz inaccesible" donde se dice que "Dios mora". Resulta invisible por su claridad deslumbradora. En un poema atribuido a Meister Eckart, Das Senfkorn (Granum sinapis, Grano de mostaza) el místico habla de un camino que conduce "a un maravilloso desierto / a lo ancho y largo / sin límite se extiende. / El desierto no tiene / ni lugar ni tiempo [...]."

\footnotetext{
${ }^{12}$ El texto orignal (,,der wek dich treit / in eine wûste wunderlîch, / dî breit, dî wît, / unmêzik lît. / dî wûste hat / noch zît noch stat [...]") se encuentra en Ruh, K., Meister Eckhart:
} 
El desierto, ese bien / nunca por nadie pisado, / el sentido creado / jamás allí ha alcanzado: / es y nadie sabe qué es. Está aquí y está allí / está lejos y está cerca, / es profundo y es alto, / en tal forma creado / que no es esto ni aquello. // Es luz, claridad, / es todo tiniebla, / innombrado / ignorado, / liberado del principio y del fin, / yace tranquilo, / desnudo, sin vestido. / ¿Quién conoce su casa? / Salga afuera / y nos diga cuál / es su forma. [... $]^{13}$

\section{Y sigue:}

Hazte como un niño, / ¡hazte sordo y ciego! / tu propio yo / ha de ser nonada, / ¡atraviesa todo ser y toda nada! / Abandona el lugar, abandona el tiempo / iy también la imagen! / Si vas sin camino / por la senda estrecha, / alcanzarás la huella del desierto. ${ }^{14}$

En su "Sermón sobre el templo vacío", Meister Eckhart habla del alma del hombre como templo que Dios quiere dominar y "esa es la razón por la que Dios quiere tener el templo vacío, para que ahí dentro no haya nada que no sea Él"15. La penetración se realiza a través de la luz: "Cuando el alma alcanza la luz sin mezcla, entonces penetra en su nonada, tan lejos de su ser creado que no puede regresar de ninguna manera por fuerza propia a su ser creado"16. En este sentido eckhartiano para Chillida la luz juega un papel importante en la no-representación o el acercamiento a la representación de lo inefable. La luz tiene una fuerza trascendental, y donde mejor se puede entender esta idea en la obra de Chillida es quizá en los canales de luz del proyecto Montaña Tindaya, en este hueco vacío en una montaña que en sí ya es un espacio mítico, un espacio sagrado. La intención del artista fue sacar 125.000 metros cúbicos de piedra y llenar el hueco, como dijo Chillida mismo, con vacío (y

Theologe, Prediger, Mystiker, München, Beck, 1989, pp. 47-51. Ver también Ruh, K., «Textkritik zum Mystikerlied 'Granum sinapis'» en Moser, H. / Schützeichel, R. / Stackmann, K. (dir.), Festschrift Josef Quint, anläßlich seines 65. Geburtstages, Bonn, Semmel, 1964, pp. 169-185 y Ruh, K., Kleine Schriften II, Scholastik und Mystik im Spätmittelalter, Berlin et al., Gruyter, 1984, pp. 77-93.

${ }^{13}$ Ibidem. „Daz wüste gût / nî vûz durch wût, / geschaffen sin / quam nî dâ hin: / us ist und weis doch nimant was. / us hî, us dâ, / us verre, us nâ, / us tîf, us hô, / us ist alsô, / daz us ist weder diz noch daz. // Us licht, us clâr, / us vinster gâr, / us unbenant, / us unbekant, / beginnes und ouch endes vrî, / us stille stât, / blôs âne wât. / wer weiz sîn hûs? / der gê her ûz / und sage uns, welich sîn forme sî.“

${ }^{14}$ Ibidem. ,Wirt als ein kint / wirt toup, wirt blint! / dîn selbes icht / mûz werden nicht, / al icht, al nicht trîb uber hôr! / lâ stat, lâ zît, / ouch bilde mît! / genk âne wek / den smalen stek, / sô kums du an der wûste spôr."

${ }^{15}$ Meister Eckhart, El fruto de la nada y otros escritos, Madrid, Siruela, 1998, p. 35.

${ }^{16}$ Ibidem, p. 38. 
luz), para conseguir una mística de la luz y de esta forma un espacio habitado por la divinidad.

Algo parecido ocurre en los primeros alabastros de Chillida, la serie Elogio de la luz. Son catorce obras, esqueletos vacíos, que buscan la forma abstracta.

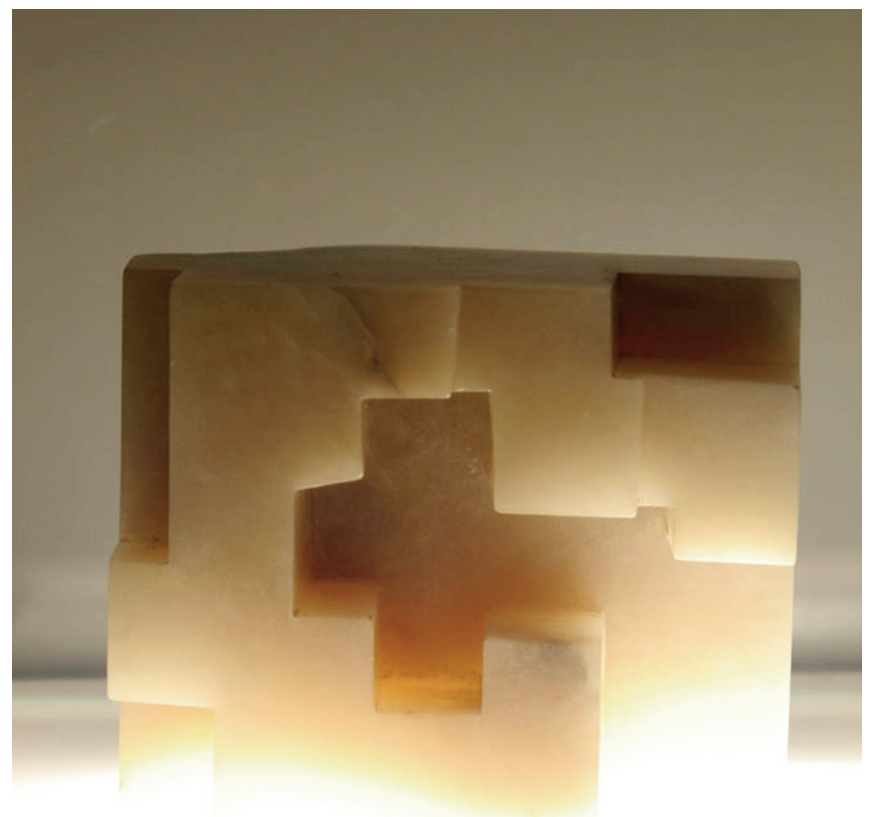

Utilizando la técnica del vaciado, la misma que ya emplearon los grandes escultores de la Grecia Clásica y el Renacimiento, Chillida horadó y modeló el bloque para que el espacio y la luz entraran en sus pétreas entrañas. Esta concepción del hecho escultórico, llevada, eso sí, a una escala titánica, sería la que iluminaría su proyecto para la montaña de Tindaya.

La luz en Chillida está relacionada estrechamente con la naturaleza. ${ }^{17}$ Para Meister Eckhart el mundo era una sola voz, un solo discurso ("ein einziges

\footnotetext{
${ }^{17}$ Llegado este momento se debe mencionar a Martin Heidegger, con quien Eduardo Chillida publicó en 1969 un libro titulado Die Kunst und der Raum. Encontramos coincidencias también en las reflexiones del filósofo alemán sobre la concepción de la luz en el pensamiento del artista español. A través de la palabra "Lichtung" (iluminación) Heidegger entiende la luz como una luz oscura, vinculada con una oscuridad denominada sagrada. Es Hölderlin quien en el poema "Andenken" introduce la paradoja del dunkles Licht, de la luz oscura. También sabía Friedrich Schlegel en su crítica a la Ilustración que lo oscuro carece de luz, pero no por ello deja de estar iluminado. La "luz oscura" del verso de Hölderlin remite a un fulgor que viene a través de su oscuridad hasta la luz. La luz oscura no niega la claridad, pero sí el excesivo esplendor, porque éste, cuanto más claro es, más firmemente impide la visión: "No sólo es
} 
Sprechen") de Dios. Toda la creación descansa en Dios como la imaginación de una mente artística. Eckhart, a través de sus numerosas andanzas, experimentó la naturaleza de forma muy intensa. En su obra se encuentran a menudo metáforas relacionadas con la exuberante riqueza de la naturaleza. Y Jakob Böhme es uno de los primeros pensadores en la cultura alemana que en sus libros habla de una confusión panteísta entre naturaleza y Dios: "So man aber will von Gott reden, was Gott sei, so muß man fleißig erwägen die Kräfte der Natur"18.

Cuando hablamos de mística tenemos que hablar también del espacio, puesto que el afán del místico se dirige a descubrir el espacio interior. La mística hay que experimentarla dentro y comunicarla hacia fuera. Es de esto de lo que se ocupa la mística, de que dominemos las fuerzas contrapuestas que nos estiran hacia arriba y hacia abajo, que les demos forma, y que al hacerlo sobrepasemos los límites, los límites del espacio y del tiempo, los límites del momento que nadie puede medir. Convertirse en servidor de esa transformación creadora es la mística; esa transmutación de la piedra, la madera y el acero sin que dejen de ser piedra, madera y acero, eso es la mística.

Veamos en este contexto una de las obras según mi parecer más destacadas de Chillida, La casa de Johann Sebastian Bach, de 1981:

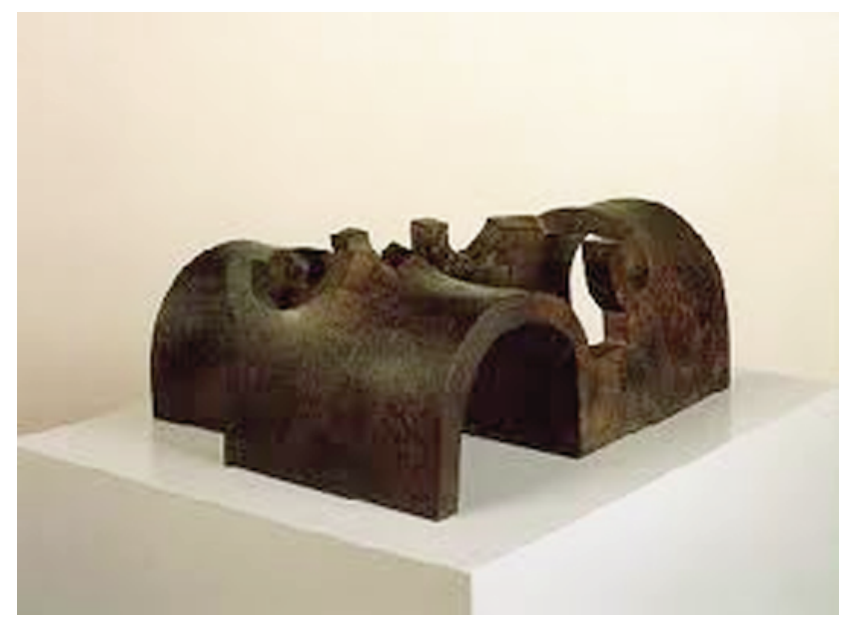

que el fuego excesivamente fogoso deslumbre al ojo, sino que la claridad excesiva absorba también todo lo que se muestre y sea más oscura que lo oscuro [...] Pues la oscuridad abre la aparición de lo que cobija, y en ésta lo cobijado en aquélla. Lo oscuro concede a la luz la plenitud de cuanto tiene para otorgar en su fulgor" (Heidegger, M., Interpretaciones sobre la poesía de Hölderlin, Barcelona, Ariel, 1983, p. 134). Véase al respecto Carbó, 1998, op. cit. (nota 9).

${ }^{18}$ Böhme, J., "Aurora oder Morgenröte im Aufgang» en Böhme, J., Sämtliche Werke. Vol. 2, Leipzig, Johann Ambrosius Barth, 1831-1847 (reprint 1922), p. 21. 
Las casas de Chillida, la de Goethe (Haus für Goethe ${ }^{19}$ ), o La casa de nuestro padre, La casa de Hokusai, La casa del poeta, recuerdan un texto de Bruno Taut de 1920 que se titula "Haus des Himmels" (casa del cielo) ${ }^{20}$ en el que el arquitecto, que por cierto tiene muchas afinidades y similitudes con Chillida, pretende construir una casa que sólo debe ser hermosa. No pretende lograr ningún otro propósito, la casa debe estar vacía también en el sentido del vacío de Meister Eckhart: "Ich will Gott niemals bitten, daß er sich mir hingeben soll. Ich will ihn bitten, daß er mich leer und rein mache; denn wäre ich leer und rein, so müßte Gott aus seiner eigenen Natur sich mir hingeben und in mir beschlossen sein“"21, es decir, Taut escribe a la manera eckhartiana que nunca le pedirá a Dios que se le entregue. Quiere pedirle que lo haga vacío y puro; porque estando vacío y puro, Dios, de su propia naturaleza, se le entregaría y se decidiría por él. Y esta casa ayudará a pasar al último punto de este artículo, es decir:

\section{"Siéntate en silencio, súmete en tiniebla" (Isaías 47,5) o la música silenciosa}

Chillida quiso encontrar una equivalencia espacial para la música de Bach y creo que la encontró en La casa de Johann Sebastian Bach aunque solo se trata de un esbozo, una maqueta para una escultura más grande. El artista se inspiró, como desveló él mismo, en el espacio interior de Santa Sofía de Constantinopla, que le parecía los pulmones del compositor alemán. También Bach, siempre según Chillida, creó espacios, pero con medios distintos a los de los arquitectos, es decir con sonidos y con el tiempo. La referencia a la iglesia, ahora mezquita en Estambul, se entrevé en la maqueta en la división en tres bóvedas, en cuyo centro entra rompiendo la luz.

Mientras que la religión se puede articular a través de contenidos y pertenece más bien al ámbito de la racionalidad, lo místico pertenece al campo de lo irracional en el sentido de la intuición y la vivencia o la experiencia espiritual. Y he aquí su afinidad con la música. En la ya citada entrevista de Chillida con Sanjuana Martínez el artista dice que

La mar es uno de mis maestros, también Juan Sebastián Bach que es muy parecido al mar. Voy a hacer un libro en Alemania con Juan Sebastián

\footnotetext{
${ }^{19}$ Según el propio Chillida la casa de un hombre como Goethe no podía tener cubiertas, la luz que él buscó será su techo.

${ }^{20}$ Taut, B., «Haus des Himmels en Stadtbaukunst alter und neuer Zeit», Halbmonatszeitschrift, Berlin / Stuttgart / Leipzig: Pontos, 1920, pp. 109-112.

${ }^{21}$ Ibidem, p. 109, cit. por el propio Taut, la traducción es de Gustav Landauer.
} 
Bach, él es el mejor arquitecto de la humanidad, solo que ha construido en el tiempo. Es mejor arquitecto que Fidias. La música es una construcción en el tiempo y en el espacio, a Bach como arquitecto no ha habido nadie que se le arrime. ${ }^{22}$

El acercamiento a Bach a través de la arquitectura está endeudado con San Agustín y su tratado sobre la música. Este escrito gira en torno a la posibilidad que ofrecía la música como camino para llegar al conocimiento, a la perfección y por lo tanto a Dios (he aquí su función también en la mística), lo que siempre despertaba en Eduardo Chillida un interés especial.

Lo más extraordinario en este contexto son los estudios inspirados en partituras de Bach. "Saludo a Bach, moderno como las olas, antiguo como el mar", es uno de los comentarios que incluyó el escultor en el libro con el que le quiso rendir homenaje y en el que incluyó once serigrafías con estampación y un relieve original para ilustrar dieciséis partituras originales del compositor alemán descubiertas en 1996. "Escultura y música tienen el mismo espacio sonoro y siempre naciente" es otra de las citas de este libro, en el que también nos encontramos con enigmas que se planteaba el artista, como "¿no son la construcción y la poesía componentes esenciales de todas las artes?" o "¿qué clase de espacio hace posibles los límites en el mundo del espíritu?" ${ }^{23}$ Cito estas frases porque están en concordancia con el pensamiento que hemos tratado a lo largo de nuestro texto. Los nexos entre el trabajo del escultor, la música y la mística quedan por lo tanto evidenciados.

La música es la base de los diálogos que estableció Eduardo Chillida con el pensamiento de los poetas místicos San Juan de la Cruz y José Ángel Valente, que en sus versos hablaban de la música como camino de perfección espiritual. Recuerdo una exposición llamada de "De música callada" (Chillida Leku, verano/otoño 2009), que hace referencia a un verso del Cántico espiritual de San Juan de la Cruz. Esta música muda no compuesta para ser escuchada sino para ser sentida, de la que también hablan los místicos alemanes, fascina al artista. En este sentido la escultura llamada "Música callada" es, según Chillida, "como una música, música en el espacio", y en vez de sonidos son las barras de hierro las que constituyen la composición. "Estas barras están orien-

\footnotetext{
${ }^{22}$ Entrevista citada en la página web de la Asociación de amigos del arte y la cultura de Valladolid: http://www.ddooss.org/articulos/entrevistas/eduardo_chillida.htm (última consulta 8 de marzo 2013).

${ }^{23}$ Lichtenstern, Ch., Chillida und die Musik. Baumeister von Zeit und Klang, Köln, Wienand, 1997; Beloubek-Hammer, A. (dir.), Chillida: Hommage à Johann Sebastian Bach, Berlin, Staatliche Museen zu Berlin. Preußischer Kulturbesitz, 1998.
} 
tadas en la forma en que la música utiliza sus poderes en el tiempo, pero yo los utilizo en el espacio. ... Es callada porque no se oye, pero se puede ver"24.

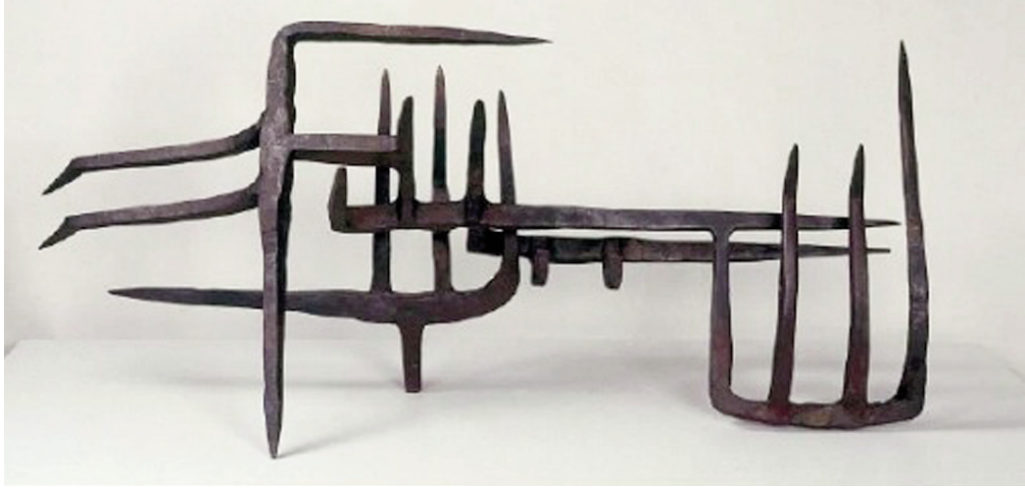

Nos podemos acercar a la relación de la música con la mística en Chillida a través de los títulos de algunas de sus obras. Ya en la primea fase de su creación encontramos trabajos como "Música de esferas", "Música callada", "Rumor de límites" u "Oyarka" (lo que significa eco) y algunas de ellas remiten a una estructura sinestésica según la cual todo el universo está sometido armónicamente a leyes matemáticas, leyes como las encontramos, según San Agustín, en la música.

Y hay otro aspecto en relación con la música que llamó la atención al escultor: el principio de la variación infinita que ofrece este arte. Bach siempre es el mismo y siempre es otro y con esta idea paradoja de nuevo se le puede acercar a la idea de lo infinito, del Dios de los místicos medievales. También Chillida destaca esta relación en su creaciones: "La música mía no es la música de los músicos. Es por dentro. Es una relación conseguida mediante una sensibilidad, quizá especial, que tengo a través de mi trabajo, para poder comunicar con ella de una manera tremenda. Desde siempre y es algo que va a más." ${ }^{25}$

\section{Final: Sub specie aeterni}

Vamos a terminar con un poema -de los tempranos (1898)- de Rainer Maria Rilke, poeta que igualmente podría haber entrado en la nómina de místicos de Eduardo Chillida:

${ }^{24}$ Cit. según Carlos Aurteneche en el diario Noticias de Gipuzkoa, 19 de enero de 2013.

${ }^{25}$ Cit. según Estela Solana en el diario digital diariovasco.com, 29 de octubre de 2009. 
Calla, de puro oír, de puro asombro, / tú, mi más honda vida; / porque ya sabes que lo quiere el viento / antes de estremecer los abedules. // Y una vez que el silencio lo haya hablado / concede la victoria a tus sentidos; / a cada soplo, entrégate y concédete: / él te amará y te mecerá. // Y entonces, alma mía, sé ancha y ancha, / que lo alcance la vida; / ensánchate como un traje de fiesta / sobre las cosas pensativas. ${ }^{26}$

Peter Sloterdijk defiende en la Kritik der zynischen Vernunft que no solamente la Wortsprache, la lengua de las palabras, quiere comunicarnos algo sino que también las cosas mismas nos hablan, hablan a los que saben utilizar sus sensores. Las cosas de las que el mundo está lleno se nos acercan por todos los lados, nos buscan con sus formas, sus colores y su atmósfera. ¿Cuál es el camino para abarcarlas? El artista (Rilke) las escucha y consigue más que entenderlas, unirse a ellas. Unirse a ellas en una actitud pacífica es la primera condición para crear una obra de arte, un poema en el caso de Rilke, una escultura en el de Chillida. Y más que pacífica esta actitud tiene que ser abierta, imperturbable y sosegada, quizá en el sentido de Peter Handke cuando habla de "sich einträumen in die Dinge" (ensoñarse en las cosas). ${ }^{27}$ No se trata de un descubrimiento o una revelación o ni siquiera un ahondamiento, sino de una experiencia empática más allá del entendimiento que podemos denominar la experiencia mística. Tiene que ver con una simpatía participativa cuya primera condición es el asombro al que Rilke alude ya en el primer verso del poema arriba citado. De este poema de Rilke me quedo con el asombro. Hay artistas que sub specie aeterni, bajo la perspectiva de lo eterno (y esta perspectiva, ya que es la mística, es la que nos ha ocupado aquí) consiguen adentrarse en las esferas que frecuentan los místicos. Eduardo Chillida pertenece sin duda a ellos.

\footnotetext{
${ }^{26}$ Rilke, R.M., Werke, Vol. 1, Frankfurt/Main, Insel, 1987, p. 154: „Vor lauter Lauschen und Staunen sei still, / du mein tieftiefes Leben; / dass du weisst, was der Wind dir will, / eh noch die Birken beben. // Und wenn dir einmal das Schweigen sprach, / lass deine Sinne besiegen. / Jedem Hauche gieb dich, gieb nach, / er wird dich lieben und wiegen. // Und dann meine Seele sei weit, sei weit, / dass dir das Leben gelinge, / breite dich wie ein Feierkleid / über die sinnenden Dinge." (tr. nuestra).

${ }^{27}$ Handke, P., Die Lehre der Sainte-Victoire, Frankfurt/M., Suhrkamp, 1984, p. 22.
} 